\title{
WRITING AS WITNESSING, POETRY AS AGENCY OF AID: THE FIVE POEMS FROM TYPHOON YOLANDA RELIEF ANTHOLOGIES
}

\author{
Vae Ann C. Dadia \\ University of Santo Tomas, Manila, Philippines \\ vcdadia@ust.edu.ph
}

Article accepted : September - $04-2020$

Revised article: November - 05 - 2020

Approved article: November - $09-2020$

\begin{abstract}
The strong typhoon Yolanda (international name: Haiyan), which buffeted the central Philippine region on November 2013 spurred the publication of several relief anthologies, so-called because they were primarily intended to raise funds for the disaster victims. This paper argues that as a distinct method of volunteerism, the poems that comprise the Yolanda relief anthologies are ecopoems which not only bear intrinsic ecological themes that confront an environment in crisis but also embody what Filipino poet Luisa A. Igloria describes as a "work of witness and deep engagement" in a time of climate and humanitarian crisis. In analyzing the five poems from two Yolanda relief anthologies, namely, Agam: Filipino Narratives on Uncertainty and Climate Change and Verses Typhoon Yolanda: A Storm of Filipino Poets, this paper utilizes the theories developed by the Filipino poets who are themselves contributors to these relief anthologies, specifically on how poetry is an act of witnessing and functions as an agency of symbolic aid. The findings contribute to the discourse on ethical literature and thus suggest that the existing brand of Philippine ecopoetry allows for poems that articulate empathic and hopeful agency towards climate-related disaster survivors.
\end{abstract}

Keywords: writing as witnessing, poetry as aid, relief anthology, Philippine ecopoems, typhoon Yolanda

\begin{abstract}
Abstrak
Badai angin topan Yolanda (Haiyan: sebutan internasional) yang terjadi di wilayah Filipina pada pertengahan November 2013 telah mendorong terbitnya sejumlah antologi relief (the relief anthology) sebagai bentuk penggalangan dana bagi para korban bencana. Artikel ini mengkaji puisi-puisi dalam antologi relief Yolanda sebagai puisi-puisi ekologis dalam Antologi relief Yolanda. Secara intrinsik, puisi-puisi ini tidak hanya mengungkap tema terkait krisis ekologis, tetapi juga mewujudkan apa yang digambarkan penyair Filipina, Luisa A. Igloria, sebagai "karya kesaksian dan keterlibatannya yang mendalam" saat terjadi iklim dan krisis kemanusiaan. Lima puisi dari dua antologi relief Yolanda, yaitu, Agam: Filipino Narratives on Uncertainty dan Climate Change dan Verses Typhoon Yolanda: A Storm of Filipino Poets, dianalisis menggunakan teori-teori yang dikembangkan oleh para penyair Filipina yang juga berpartisipasi dalam pembuatan antologi tersebut, khususnya tentang bagaimana puisi sebagai bentuk tindakan kesaksian (act of witnessing) dan sebagai agensi bantuan secara simbolik (agency of symbolic aid). Hasil penelitian menunjukkan bahwa selain memberikan kontribusi pada wacana etika kesusastraan, puisi ekologis (ecopoetry) Filipina menjadikan puisi sebagai media untuk mengartikulasikan 'empati' dan sebagai agensi 'harapan' bagi korban bencana iklim.
\end{abstract}

Kata kunci: menulis sebagai kesaksian, puisi sebagai bantuan, antologi relief, ecopoems Filipina, badai topan Yolanda. 


\section{INTRODUCTION}

On the morning of November 9, 2013, residents in Leyte and the coastal villages of Eastern Samar, Philippines, realized it was not enough that they made it through the night. That day turned out to be just the beginning of the many days of surviving the bedlam. Being in the areas worst hit by Yolanda, "one of the strongest storms recorded on the planet" (Mullen, 2013), thousands of Visayans ${ }^{1}$ braced themselves for the worst: living without shelter, food, clean drinking water, and locating and burying their dead.

The destruction that typhoon Yolanda caused in its path was matched with an immense outpouring of sympathy and aid from everywhere. Huge relief efforts from the international community were mobilized as soon as possible for fear that more could die in the wake of the disaster. As nations rushed in for critical aid, local personalities and private citizens organized independent outreach projects. It was a period that North American disaster researchers describe as "a time of community consensus and solidarity" (Hannigan, 2013: 8) when "people come together to plan, coordinate, and expedite effective action, only to disband when the period of crisis ends" (Solnit, 2010: 2).

The Filipino literary community partook in this moment of collective action through the publication of relief anthologies, so-called because they were primarily intended to earn proceeds for the typhoon victims. The relief anthologies demonstrated a new possibility in Filipino volunteerism. It became a distinct relief/aid operations endeavor, one that was spearheaded by writers whose target respondents were a specific group of individuals - their fellow writers - to solicit from them a donation of talent, i.e. in the form of their literary works.

This paper argues that the five poems selected from two relief anthologies, namely, Agam: Filipino Narratives on Uncertainty and Climate Change and Verses Typhoon Yolanda: A Storm of Filipino Poets are what Filipino poet Luisa A. Igloria describes as a "work of witness and deep engagement" in a time of climate and humanitarian crisis. The method of analysis involves a close reading of the selections and utilizes the theories developed by the Filipino poets who are themselves contributors to these relief anthologies. This paper aims to contribute to the current discourse on ethical literature, specifically by illustrating how poetry is an act of witnessing and functions as an agency of symbolic aid, and to suggest that the existing brand of Philippine ecopoetry allows for poems that articulate empathic and hopeful agency towards climate-related disaster survivors.

\section{FINDING AND DISCUSSION}

\section{"Aid is art": The Relief Anthologies Verses and Agam}

In his poem "Ballade: Instructions to an Aid Worker," Dumdum (2014: 45) declares, "aid is art". This succinct remark best describes the efforts of the editors and the contributors of the relief anthologies in their initiative of putting 
together a literary collection through which they can generate donations for the survivors of typhoon Yolanda.

"Relief" was a buzzword in the period that followed the catastrophic event. New World Encyclopedia defines "relief" in emergency and disaster parlance as "the monies or services made available to individuals and communities that have experienced losses due to disasters such as floods, hurricanes, earthquakes, drought, tornadoes, and riots." It was Dean Francis Alfar who ascribed the term to his book project Outpouring because the anthology, he said, was conceptualized first and foremost out of a response to a period of crisis.

What is worth emulating in this unique relief-volunteerism effort, as Vince Gotera (2014) observes is that it proves the proverbial "power of the word" evident in the poetic response of the Filipino literary community motivated by their faith in their craft's ability to move and transform society. Melissa Sipin describes this form of literary-cum-social initiative as the art of call-and-response:

"But within these moments of tragedy, many writers and artists gathered online and encapsulated their shifting emotions in art ... When Juan Felipe Herrera, the Poet Laureate of California, and poet Vince Gotera sent out a call for poems of uplift and healing on the Facebook group, "Hawak Kamay: Poems for the Philippines After Haiyan," the group epitomized the power of the Filipino collective psyche: kapwa (togetherness), kagandahang-loob (shared humanity), and pakiramdam (shared inner perceptions). This great tragedy tied the community together-and in turn, our art shifted into a call-and-response against tragedy."(Gotera, 2014)

Sipin further asserts that Verses, as well as the rest of the relief anthologies, is a "communicative act of healing" that exemplified the "[Filipino literary] community uniting during tragedy and through the strength of literature." The majority of the information regarding the making (and completion) of Verses was provided by the writers who are themselves part of this book project, either as a contributor of poems or as an editorial consultant. In this regard, the Filipino writers behind this project operated under the idea of embodying the notion of kapwa, which they claim are very much intact among Filipinos. For Sipin, whether Filipinos call themselves or like to be called resilient or strong is acceptable, for these terms are mere denotations of the "power and emotional truth [...] that gravitate around the fabric of kapwa, of kagandahang-loob, of pakiramdam" (italics in the original).

Meanwhile, Tabios (2014) claims that the anthology is created to raise funds that shall be used for the rebuilding and rehabilitation of the communities and the creation of livelihood programs that would help the Yolanda survivors get back on their feet. Tabios admits that during the completion of this book project, she asked herself several times about what could be more important than the material aid these relief anthologies are made to provide for. The answer, she believes, lies in the act of writing about the experience itself. 
Strobel (2014:13) believes that the immediate aftermath of typhoon Yolanda was an opportune time to confront the question, "What are poets for?". A large part of the Filipino literary community heeded this rhetorical call that led to the convocation in the form of the relief anthologies. Besides the given fact that these books are made for charity, Strobel commends the editors and contributors for addressing the moral and ethical aspects of the Yolanda tragedy. It entails the task of narrating the stories of loss and trauma of the survivors who had been in the "frontline of the disaster," the adverse effects of climate change and environmental degradation, and the challenges of moving on from such an ordeal which consequently touch on the discussions about Filipino resilience, and more importantly, our disaster preparedness and ecological sustainability.

In his Introduction to Agam: Filipino Narratives of Uncertainty and Climate Change, publisher Constantino (2014: xix) asserts, "The things that matter always begin with stories". Barely a year after the onslaught of Yolanda, Constantino and his team from the Philippine-based Institute for Climate and Sustainable Cities released a literary anthology in the size of a coffee table book featuring the massive devastation of Visayas through poignant colored pictures of the victims and the affected areas, with text pairings courtesy of the country's acclaimed writers.

Agam (2017) contains prose and verse in English, as well as in Filipino, Sinama, Magu- indanao, Bicolano, Cebuano, Tagalog, Ilocano, and Waray, all of which are provided with English translations by the authors themselves. This is noteworthy because even if the writerscontributors do not come from the areas directly affected by typhoon Yolanda, their choice to write in the regional languages allows them to speak in behalf of the survivors. It may also be interpreted as a gesture of sympathy to those who have experienced the calamity firsthand, thus may be taken to mean that everyone is vulnerable: What happened in the Visayas can happen elsewhere in the Philippines. Francia (2014) describes such an act of solidarity as "humanity as the 'eye' and 'I' of the storm." There is no room for indifference to the kapwa in a period of crisis. In a time of community consensus, the existential I is drowned in the multitudinous I's, creating what Sipin (2014) calls "a rhythmic chorus that becomes a surge of collectiveness and oneness"-of shared humanity.

\section{The Yolanda Poems as Ecopoems}

As ecopoems, the poems that comprise Verses and Agam are founded on various ecological issues of an environment in crisis, among which are: 1) disasters as inexorable forces of nature; 2) disasters that are not in the strictest sense man-made, but are caused by man's exploitation of their natural dwelling; 3) the anthropocentric concept of sustainability; and 4) climate change which is purported to have engendered typhoon Yolanda. As an archipelago of roughly 7,100 islands and which sits 
within the so-called Pacific Ring of Fire, natural disasters especially tropical storms are expected, if not altogether common for most of the Philippines. This geographic vulnerability configures the collective disaster imagination of Filipinos, as evidenced by how disasters and the disaster experience find significant representation in popular culture. In his poetry collection Islands of Words \& Other Poems, Yuson (2015: 19) has this to say about the Philippines: "You need to understand that our nation is made up/ of 7,107 islands; nearly everything is by the coastline//". Igloria (2014: 148), in her poem "Afterward," calls the Philippines the "republic of the drowned". Meanwhile, Santos (2011: 67) cites that the Bicol region has been dubbed "Republika ng Kalamidad" and "Orinola ng Bayan". All of these observations allude to the country's vulnerability to typhoons (and the further destruction that they entail, e.g. landslides, flash floods, storm surges, and the like), as well as a spoken intuition on the psyche of the Filipinos living in this kind of reality.

Arigo (2008) describes the purview of ecopoetry as the "explor[ation of the] creative-critical edges between writing and ecology." He forwards the view that an ecopoem is founded on "the tension between the cutting edge of innovation and ecological thinking," and observes that "much of the ecopoetry being written seems to take place more in the realm of the innovative, as opposed to more mainstream poetries because innovative po- etries are loci of resistance to mainstream poetic practices (and values) which presumably reflect larger social paradigms". As an artistic representation of the environment, ecopoems provoke new readings of human-nature relationships and have the potential to bring important and sometimes neglected perspectives on ecological issues to the fore. Thus, as ecopoems, the Yolanda relief anthology poems invite readers, especially Filipinos, to reflect not only on our ecological history or "ecological indigenousness" (Chua, 2017) and disaster susceptibility but also on the related issues that Yolanda has given rise to, such as our moral obligation with the natural dwelling that sustains us and with our fellow human beings.

\section{Writing as Witnessing, Poetry as Agency of Aid}

In his article, "'Our Common Sufferings': Reflections on the Ethical Dimensions of Contemporary Disaster Poetry," Wang (2009: 115) argues that Adorno's declaration that "[writing] poetry after Auschwitz is barbaric" had initially hindered the ethical turn poetry is supposed to take. Wang (2009: 115) asserts that poetry is a more potent literary form to articulate a traumatic ordeal because he considers this "old literary form [...] to have magic wings, flying from the border to the center of life and man's vision". Here, he acknowledges that poetry is an intuitive art, and through its structure and metaphoric language, can render the experience more intense and profound. In this new millennium, which saw many kinds of suffering in the 
form of natural and man-made disasters, Wang (2009: 114) calls for a "breed" of poetry that addresses the impact of horrific events. Such poetry, he posits, should explore the complex relationships between poetry and ethics in three aspects: 1) the silent witness; 2) the traumatic memory; and 3) the ethical act of contemporary disaster poetry, which jointly makes up the multi-ethical dimensions of disaster poetry.

Meanwhile, for Antony Rowland, poetry's built-in "precociousness" is the "very principle of poetic insight and the very core of the event of poetry' [...] poetic language speaks ahead of knowledge and awareness and breaks through the limits of its own conscious understanding" (Rowland, 2014).

However, since the poems are not written by the Yolanda survivors themselves, should they be considered factual and reliable resources on the disaster experience? This can be addressed by arguing that literature, by its mimetic ability, functions as a mirror and a critique of the reality that it represents. As a critique, May (2007: 95) believes that literary narratives "open new possibilities of being" and "can crack the eggshells of long-standing ideological paradigms". Further, literature in its representational mode enables writers to function as an intermediary. Luisa Igloria describes it as the state wherein the poet is "naluganan" (mounted) and becomes a vehicle (literally a transporter of the message), recalling certain shamanic traditions in Phil- ippine culture and literature:

"When the babaylan or mambunong (the priestess-medium, who is also a rhapsode and poet) falls into a trance and begins to speak in other voices, the condition is described in one of the vernacular languages as "naluganan"-quite literally, the state of being mounted (as a steed would be mounted) by an unnamed power-the divine masquerading in another form (s). The poet-medium is never entirely erased in the process, nor simply reduced to a mechanism of levers and pulleys to throw the voice or thrash the limbs about for dramatic effect. Despite the apparent submersion of her own physical identity, she must be an active, muscular and facile vehicle; the animal (though haltered) whose nose points too toward the goal of poetic or divine utterance-ideally, the state in which steed and rider blur and become indistinguishable from one another (qtd. in POEMELEON; emphasis in the original)."(Agam, 2017)

Romulo Baquiran Jr.'s brief story about writing his poem for Agam using the technique of ekphrasis, and of reading the works of his cocontributors reinforces Igloria's concept of the poet-medium:

"[N]akita ko na ang basic na damdamin was really compassion [...] at sa mga writers, dahil compassionate, awa o pakikiisa. Sabi ng isang psychologist ang Filipino ay mayroon daw seven steps ng Filipino pagkikipagkapwa. It begins with patanongtanong, kikilalanin mo lang [then] palapitlapit. The final stage is pakikisa-when you become one with the other. Pero itong mga writer, meron pang isang level. Hindi lang pakikiisa, kundi nung tinignan ko ang mga poems nila-nasapian! Kumbaga, dialectical kasi yung relationship. Habang tinitignan mo yung picture [the commissioned photographs in Agam], tumitingin din sayo yung character and nagkakaroon kayo ng connection. The character becomes you, and you become the character." (Agam, 2017) 
[What I observed to be the basic emotion was really compassion [...] and among writers, since they are compassionate, empathy, or solidarity. One psychologist claimed that Filipinos follow the seven steps to camaraderie. It begins with the act of asking around, getting to know, and going around \{people and the circumstances\}. The final stage is unitywhen you become one with another. However, with these writers \{relief anthology contributors\}, there's another level \{step\}. It's not just unity but, if you'll look closely at their poemspossessed! The relationship is dialectical. While you look at the picture [the commissioned photographs in Agam], the character or the subject\} on the picture gazes back at you, and you develop a connection. The character becomes you, and you become the character.]

Significantly, Baquiran refers to the state of becoming "nasapian," a term equivalent to Igloria's "naluganan," to describe that writing the Yolanda poems is to be moved or claimed by an "unnamed spirit, divine power, or force," and in which process the poet becomes the medium of "poetic or divine utterance" (Poemeleon, 2005).

Baquiran (2017) also refers to the compassion that is intrinsic among writers, which for him enables the poets to enter into a "dialectical relationship" between the survivors. He further maintains that this relationship is founded on camaraderie ("pakikiisa", "pakikipagkapwa") resulting in a deep sense of connection wherein "the character [addressee/survivor] becomes you, and you [poet] become the character."

\section{The Five Yolanda Poems}

The Yolanda survivors, traumatized and preoccupied with rebuilding their lives and finding ways to sustain their livelihood, hardly had time to reflect on the immediate aftermath of their tragedy. However, their disaster experience is retold through these poems, and in this way, the poems are transformed from being merely poetic expressions into a medium that makes possible the confluence of the voices of the writers and the survivors.

As soon as the vastness of Yolanda's destruction became apparent, the rest of the Philippines as well as the whole world were riveted by the images of the aftermath that flashed on news headlines for days. Disaster scenarios are all-too-familiar to Filipinos especially in the wake of a tropical storm, but what they saw at the time were extraordinary and frightening: one of the strongest typhoons that hit land buffeted the central Philippines, leaving millions displaced and thousands dead, and reducing a large portion of the region in rubbles.

In the coastal areas of Eastern Samar, "rubbles" was not even a fitting term because the small communities had been totally washed out by the repeated strong storm surges (Romero, 2017). As humanitarian relief teams worked hard to assess the critical situation and provide aid, immediate attempts to describe the catastrophe mostly came from outsiders in their safe observer's distance.

This is what Luisa Igloria's poem "Afterward," written just days after Yolanda's 
strike, exhibits. We cannot say who is describing the scene in the poem. It could be Igloria herself, speaking from her point of view as a Filipino expat writer watching the news from overseas of what had happened to her homeland. It could also be anyone watching the news as reporters on the ground try their best to cover every affected area as comprehensively as they could.

The descriptive enumeration of what is apparent in the aftermath of the disaster is sustained until the end of the poem. While this technique lends the piece a tone that seems distanced from the subject, the details that the poetic persona gravitates on reveal their emotional entanglement. The images in the poem are not conjured; in fact, these kinds of images proliferated in the wake of Yolanda. But news reports ironically lack in detail. They are a vital source of information on the total worth of properties destroyed, the tally of casualties, and the present condition of survivors, yet television spectacles tend to remove the emotional intimacy of pain. The persistent circulation of data also runs the risk of mindless spectatorship and diminished emotional responsiveness among viewers.

Strobel (2014: 13) asserts that the power of the poetic language lies in its ability to speak of something other than how news reportage informs. Poetry, she says, deploys tropes and images that "[tease] out the ineffable" to "make us ponder" and see beyond what is. As opposed to a news reportage that is the work of a supposedly unbiased and emotionally detached journalist, "Afterward" promotes poetry as "a work of witness [that] offers a path to more active and humanizing witness, deep engagement, and hopeful agency" (Igloria, 2017). It would have been easy for people to dismiss what they witness or simply look away. But for Strobel, as for Igloria, art should not leave us cold, thus they believe that poetry is a medium for witnessing-a necessary and humane response in these times that are "no less rife with [...] crisis, degradation, and violence" (Igloria, 2017).

At this point, Igloria's operationalization of the term "afterward" is acknowledged. Instead of the noun "aftermath," which pertains to the period shortly following an incident and which is more commonly used in the context of a postdisaster scenario, Igloria utilizes "afterward" which denotes a subsequent, future time. As an adverb, the syntactic function of afterward is to modify and describe other linguistic elements, such as adjectives and verbs. The implied verb in the poem is "live/survive." The adverb afterward, therefore, intensifies the impact of the verb live/survive by leading the readers to imagine a future scenario after the storm, a much later time when the repercussions of the tragedy are sinking in. This technique also works in helping the readers arrive at a delicate realization on how the survivors hold out even after everything that they need to survive on has been destroyed.

This is where the details in the poem bear more weight: Is there a chance for a newborn 
and his mother to survive in "an edifice half on stilts and half unroofed"? Is there nourishment obtained from "the bread of nothing and the salt of nothing and the crust of nothing freely shared"? What kind of moral dilemma do the aid workers confront in knowing that their "cargo of bottled water" and relief supplies cannot meet the needs of all the hungry, desperate survivors? "Afterward" presents the human side of the post-disaster scenario which generic statistics and data cannot articulate. Its most powerful component is the title itself, which suggests survival long after the storm has passed.

A display or an expression of emotional attachment is also at risk of being viewed as plain melodrama. And so, where the speaker in Igloria's piece consciously focuses their attention on the images of destruction and loss, thereby stirring the emotions of readers, the envoi in Simeon Dumdum Jr.'s "Ballade: Instructions to an Aid Worker" is to keep the addressee's (aid worker) emotions in check.

Managing one's emotions amid distressing circumstances is necessary so that they cannot be distracted from the task at hand. Just like in the poem "Afterward," the poetic persona in Dumdum's ballade is aware of the emotional hold of the post-disaster scenario, as implied in the lines: "Now you must be hearing their cry/ The wind and waves have stripped them nude"; "I know that you might wish to die/Seeing the lifeless children blued." Thus the aid worker has to be constantly reminded to focus and fulfill their mission.
However, the aid worker in the ballade, as opposed to the location and point of view of the speaker in "Afterward," is not witnessing the aftermath in their safe observer's distance. As part of emergency response teams, aid workers are often the first on the scene. Their exposure to the disaster may be less direct, but it still renders them vulnerable to trauma just as the primary victims (i.e. typhoon survivors). The ballade assumes a tricky point of view. On initial reading, it appears that the poetic persona and the addressee/aid worker are separate entities. But a close reading offers the possibility that the speaker is being reflexive; the "you" does not necessarily function as an apostrophic device, but also gives us the impression that the speaker is referring to itself as if in some sort of a monologue. This self-reference is thus likened to a pep talk that people engage in when they build up courage or prepare themselves for the task at hand. International aid worker Sandra Bulling, who had flown in the Visayas soon after Yolanda's landfall, echoes such mood:

"The destruction from the storm surge that came with the typhoon is apocalyptic. Driving along the coast, we smell decayed bodies. There are corpses under the rubble. We start to cry in the car and for a while, I can only look straight ahead, not daring to glimpse through the side windows. No matter how experienced you are, seeing dead bodies still shocks you to the core. Looking into the eyes of survivors is not easy either [...]."(Bulling, 2013)

Bulling's story about her work during the post-disaster Visayas provides an insight into the delicate position of volunteers as witnesses. 
These volunteers are rescue agencies on a mission, but as emotional beings they also need a moment to process the magnitude of what they witness (Seeing the lifeless children blued/ By hours; Already, the people have chewed/ Everything but food), to remind themselves of their purpose, and to recharge and find reasons to keep going. The instruction of the speaker in Dumdum's ballade is phrased in different ways-you have no time to brood/ And whatever may be your mood; You have to meld your mind and heart/Begin your task, do not be rude; Just do your work and then conclude-but in essence, they all mean the same. Bulling's own story affirms it: personal emotions should not get in the way because as a volunteer the priority is not the self but those in need. The ballade shows that this extraordinary self-control that comes with the role of a volunteer is a skill, a talent, so much that the speaker declares: "[A]id is art-."

Further, aid work is an act of mercy. Volunteerism by definition is an altruistic commitment of providing aid and assistance for no remuneration or recognition. The linking of volunteerism to the act of mercy is accomplished through the ballade's refrain, empty yourself and then depart, which calls to mind the Catholic Prayer to the Divine Mercy:

You expired, 0 Jesus,

but the source of life gushed forth for souls and an ocean of mercy opened up for the whole world.

0 Fount of Life, unfathomable Divine Mercy, envelop the whole word and empty Yourself out upon us.

(The Divine Mercy, 2007)

The prayer recalls Christ's ultimate sacrifice, His Passion on the Cross for our salvation, for which He asks us to "immerse ourselves" because it is at this hour (three o'clock) that we "can obtain everything for [ourselves] and for others for the asking; it was the hour of grace for the whole world-mercy triumphed over justice"(The Divine Mercy, 2007). The ballade's refrain, "empty yourself" [out upon the survivors] is an evocation of the prayer and raises the ballade to the level of spirituality. Not only is the verse repeated in all stanzas, but is also made to be the closing line of each stanza, to emphasize that volunteerism is an act of mercy, and the aid worker's sacrifice for the survival (salvation) of the typhoon victims.

The disposition for mercy and "active, humanizing witness" is what the speaker in the next poem seeks (Igloria, 2017). In Merlinda Bobis' "Ten Fingers," tragedy hits close to home, leaving the expatriate speaker desperate for empathy from anyone who has heard of (or watched) typhoon Yolanda (Bobis, 2014).

As explicated in Igloria's "Afterward," more than the actual tragedy of Yolanda's catastrophic hit is the tragedy of its repercussions. In "Ten Fingers," tragedy strikes the speaker twice: first, she has to endure the pain of the distance from her parents upon hearing the news of Yolanda; and now, she is wrestling with the possibility that there is nothing left for her to come home to: 
So now, I'm at the L.A. airport, going home to what

I don't know. To what I can't see in the news: our house,

our farm, my father, my mother. I can't see them, or the

impending landfall in my chest.

(Bobis, 2014)

A calamity of such magnitude is indeed a national tragedy, but for the victims and survivors, Yolanda is a personal tragedy, and the grief that it brought upon them could not be completely understood by outsiders. That is why the speaker in "Ten Fingers," as in the poem "Afterward," insists that we grasp beyond the collective statistics generated through news reportage. She pleads the outsiders-witnesses-those "gasping/ at this tragedy on TV, on [their] laptops and iPhones" to "see what can't be seen." It is an appeal to the humanity of outsiders-witnesses to recognize the dignity of these people who are casualties of the storm and have been rendered nameless and faceless by the news, among them the one's dearest to her.

Besides a plea, the poem gives the impression of a tribute accorded by a daughter to the memory of her parents. But nobody could know her parents-their daily struggles, their trials, their sacrifices-as much as she does:

[...] The many times in a year of fixing the roof wrenched away by the many storms. The many times of evacuating because of the flood. The many times of scavenging for rotting rice.

\section{Ten}

strong fingers in the mud, on the plow and the buffalo, on

the rice-grains, on his knees that always ache at night.

(Bobis, 2014)

Adding to the speaker's struggle is her attempt to make the outsiders see her parents $(A$ beautiful picture of my most beautiful father/ I wish to pass his face around, to all the passengers lining up towards the plane) the way she sees them because it is a violation of their memory not to be honored for who they are and how they live their life. We thus understand that the "ten fingers" are: 1) a synecdoche to represent the totality of the two individuals that Yolanda may have possibly (or has) taken away; and 2) as a metonym that is substituted for the diligence, as well as the sacrifices, of these two individuals: "It is my father, my/ mother and all of twenty fingers holding back this storm."

In the last lines of the poem, the speaker's plea becomes more insisting: "Please, I beg/ you. Look closer." She seems to have been rendered irrational by the sheer grief and the muddle of emotions (heartbreak, desperation, loneliness, self-pity) meted out by this collective tragedy which, ironically, she knows she alone must endure.

"Ten Fingers" is a compelling and powerful poem because it stirs the readers-witnessesoutsiders-or those that did not have to personally deal with the blow of Yolanda-from indifference to empathizing and becoming an 
"active witness" (Igloria, "Don't Look Away"). The poem is a vicarious testimony at its best, as it reminds us that a Yolanda survivor and victim's story is not merely her own, but of all of us.

As in "Ten Fingers," the next poem, "Diptych, Hindi Selfie" by Ramon C. Sunico (2014) begs for the witness-outsider's attention to their urgent condition. The poem concretizes the words "empathy" and "mutualism" by being symbolized by the diptych, which is preferred over the selfie. The trope of the diptych represents a relationship based on mutualism and founded on empathy, and through which the addressee is urged to see themselves in the image of the speaker, and vice-versa.

The repetitive call, "Dali. Dali!" is fraught with urgency because the fast-changing climate conditions, according to the speaker, are threatening to obliterate them (bago tuluyang mawala; hanggang lahat nito'y mawala; tuluyang matatangay). The speaker's description of their current situation is concomitant with the changes observed in the environment (as illustrated in the poem "He Said"). For example, reference is made on the waning resources (Ngayo'y mayroon pang pawid/ at kalabasang tinda), and the worsening landscape (may landas pa sa lilim/ nitong mga sanga-sanga) which is very quickly turning into a perilous to place to live in (Ngunit kay daling maging ilog/ ang maalikabok na daan [...] taksil na baha/ na nagkukunwaring maamong/sapang pampalamig ng paa).
The plea of the speaker for the addressee to take their picture (mamang/ may camera. Kunan nyo na po ako) must not be taken as it is, i.e. as a trivial desire to be the subject of a stranger's gaze. As the central idea of the poem, the plea for a photo opportunity is a symbolic call to action in the hopes that the addressee may be moved to do something for the speaker after their attention has been called towards the latter's current condition.

Finally, as in the previous poems under the present subsection, "Diptych" inquires to what extent we are willing to dedicate ourselves, and how far we are moved to act (deep engagement and active, humane witnessing) amid a humanitarian crisis.

Meanwhile, the next selection warns of the danger that the act of volunteerism and relief donation is reduced to a mere "ritualistic performance during the post-disaster period (Chua \& Mendez, 2015). "To the Donors" by Roger B. Rueda (2014) is a reminder that active engagement in a period of the humanitarian crisis is also constituted by the extra measures we are willing to undertake so that the help we extend is especially solicitous and essential.

The speaker aims at the lack of empathy from the part of their relief goods donors. The tone is not to be mistaken as the speaker's-the typhoon survivor and recipient of the reliefungrateful lash at their sponsors. Rather, their dissatisfaction is contained by the sarcastic overtone delivered in lines such as: "You must be a great psychic./ Yes, this is my dream [...]." Further, the poem gives an idea of the kind of 
relief goods handed out to the Yolanda victims: that not only are the supplies unessential in the context of the speaker's urgent condition, but they also reach the level of absurdity.

The line "Thanks for the fur coat" enhances the derision. The relief goods cited in the poem, starting with what the speaker has with them, are unnecessary and absurd specifically for the following reasons which the speaker enumerates: the "high heels" and the "flowing black gown" are not suitable since "the streets of Tacloban/ have been reduced to rubble." Also, a "fur coat" is unnecessary in such "a hot, humid day" and "[b]esides the whole city/ doesn't have electricity yet." Next, the "high boots" the speaker has on and the "Snow White dress" are definitely not comfortable to wear especially if they have chores to attend to: "when I help my mum/ sell rock salt looted by dad/ two days ago," but readers get the impression that the speaker has no choice but to use them since they are left without a piece of belonging after the typhoon.

The speaker then turns to their family to check what they received for themselves. The siblings "enjoy eating/dry noodles" not because they taste like how noodles are supposed to, but because eating them is like "Chippy," a local junk food. In this specific line, the poem offers a critique of the practice of relief goods donation in the country. First of all, common sense is necessary because it grants the donors the foresight so that they can easily pick which supplies are urgently needed. In the immediate aftermath of a typhoon, it would not have been convenient for the survivors to consume packed goods that still have to be cooked (e.g. noodles). Further, it would take time before the goods are distributed to the affected areas, for they still have to go through several processes, including the preparation, repacking, and delivery. As such, the food commodity must not be easily perishable.

Meanwhile, the speaker's mother "looks like/ Ariella Arida in her yellow gown" and the father "looks like/ a chef from a five-star hotel" who lacks a beret. Altogether, they look like a ludicrous bunch all because the supplies that have been handed to them are dole-outs from neither mercy nor sincere help. These donations are not the type of supplies that would be put together by supposedly concerned witnesses-donors; from the description of the speaker, the goods that have been handed out to them are leftovers, of which the donors no longer find useful and thus "dispose" them as "relief."

Chua \& Mendez (2015) cite this kind of "volunteering activity" performed by donors only so that they can "connect with the event or to 'come to terms' with it" as "ecominstrelsy" ("0-Plan Tabang"). Quoting Theresa J. May, Chua \& Mendez (2015) argues that the opportunities for volunteerism in a postdisaster period are in danger of inviting participants whose engagement is not defined by a sincere desire to aid or provide assistance, but by "self-gratification," or of assuaging their guilt by convincing themselves "that they have 
done something, anything to help their fellowmen who were in need".

Finally, the derision in the lines, "Oh, wait a minute./ Everyone wants to take/ a photograph of us" is a strike against outsiders who are offensive to the survivors for demonstrating no decency in objectifying the typhoon victims after they have been rendered in such miserable condition than they already are because of Yolanda.

\section{CONCLUSION}

This paper has strived to source local writers and scholars, for who can understand better the psyche of Filipinos than Filipinos themselves? The poems tackle the Yolanda disaster experience to reveal not only our susceptibility to calamities given our archipelagic location but more so the value that Filipinos hold toward each other. The Yolanda relief anthology poems have demonstrated the very capable role of Filipino poets, and in turn literature, in commemorating, catharsis, and insistence on human sensitivities during "intense moments of subjective experience" in Rowland's Poetry as Testimony 1, thus, as Wang said before, collective traumatic events such as Yolanda happen, we as a people are not prone to "brutalization and indifference".

The Yolanda relief anthology poems also exemplify what Luisa A. Igloria identifies as the qualities of poetry that make it a more suitable literary form for trauma and disaster narratives. Igloria's concept of poetry and the work of witness bears the catchphrase,
"Don't look away," appropriately so as it promotes poetry as a path to more active and humanizing witness, deep engagement, and hopeful agency in a time "no less rife with situations and events that compel and immediate and ethical response to a crisis, degradation, and violence." Poetry, Igloria argues, is the answer to this increasingly "complex and volatile world, [where] it is easy to feel increasingly bewildered and bombarded by the digital-easy to feel as if at once connected, and at the same time separate, from the ways, others experience daily life, struggles, sorrows, joys, hopes...".

Finally, this paper addresses the issue that the act of writing a traumatic experience is neither exploitative nor self-serving because, according to Antony Rowland, while the poems under study are not strictly classified as testimony poetry, i.e. that it is not the Yolanda victims themselves who penned the poems, the very form by which these narratives are written makes the disaster experience trauma "resistant to the proliferation of testimony in the public sphere". Rowland further claims that writing about a traumatic experience is a moral obligation and that poetry ought to consider "life itself and [its] duty as the ethical imperatives of witnessing, testifying and memorializing".

\section{Notes}

Visayans are a Philippine ethnolinguistic group native to the whole Visayas (central Philippines) as well as to many parts of Mindanao (southern Philippines). 
Poetika : Jurnal Ilmu Sastra

Vol. 8 No. 2, December 2020
DOI 10.22146/poetika.59485

ISSN 2338-5383 (print) ; 2503-4642 (online)

\section{REFERENCES}

Agam. (2017, August 2). Romulo Baquiran on Agam. https://agam.ph/2017/08/03/ insights-by-romulo-baquiran/. Accessed 13 December 2017.

Arigo, C. (2008). Notes Toward an Ecopoetics: Revising the Postmodern Sublime and Juliana Spahr's This Connection of Everyone With Lungs. How 2, 3(2).

Bobis, M. (2014). Ten Fingers. In Regina Abuyuan (Eds), Agam: Filipino Narratves of Uncertainty and Climate Change, (p. 40). Quezon City: ICSC.

Bulling, S. (2013, December 21). Typhoon Haiyan: An Aid Worker's Diary of a Disaster. The Guardian. https:// www.theguardian.com/world/2013/ $\mathrm{dec} / 22 /$ typhoon-haiyan-philippines-aid -workers-diary-of-disaster. Accessed 17 July 2017.

Chua, R. G. (2017). Introduction. In Rina Garcia Chua (Ed), Sustaining the Archipelago: An Anthology of Philippines Ecopoetry, (pp. xxv-2). Manila: UST Publishing House.

Chua, R. G., \& Mendez, Em. (2015). 0-Plan Tabang: Eco-Minstrelsy as Ritual and Performance in Volunteerism aft er Haiyan. PSi\#21 Philippines: Performance, Disaster, Resilience (Sa Tagilid na Yuta: On Tilted Earth: Performance in Archipelagic Space), November 5, University of the Philippines, Diliman, QC, Philippines.

Constantino, R.R. (2014). Introduction. In Regina Abuyuan (Ed), Agam: Filipino Narratives of Uncertainty and Climate Change, (pp. xvii-xiv). Quezon City: ICSC.

Dumdum, S. Jr. (2014). Ballade: Instructions to an Aid Worker. In Eileen R. Tabios (Ed), Verses Typhoon Yolanda: A Storm of Filipino Poets, (p. 45). Philippines: Meritage Press.

Francia, L. H. (2014, December 10). Humanity as 'eye' and "I" of the storm. Inquirer. http://

globalnation.inquirer.net/115330/

humanity-as-the-eye-and-i-of-the- storm. Accessed 20 April 2017.

Gotera, V. (2014, March 21). Hay(na)ku after Haiyan. The Man with The Blue Guitar. http://vincegora.blogspot.com/2014/03/ haynaku-after-haiyan.html. Accessed 21 Feb. 2017.

Hannigan, J. A. (2012). Disasters without Borders: The International Politics of Natural Disasters. Cambridge: Polity.

Igloria, L. A. (2014). Afterward. In Eileen R. Tabios (Ed), Verses Typhoon Yolanda: $A$ Storm of Filipino Poets, (p. 148). Philippines: Meritage Press.

-------. (2017, January 7). Don't Look Away: Poetry and the Work of Witness. http:// www.luisaigloria.com/dont-look-awaypoetry-and-the-work-of-witness/. Accessed 17 January 2018.

May, T. J. (2007). Beyond Bambi: Toward a Dangerous Ecocriticism in Theatre Studies.Theatre Topics, 17 (2), 95-110. https:// doi.org/10.1353/tt.2008.0001.

Mullen, J. (2013, November 8). Super Typhoon Haiyan, One of Strongest Storms Ever, Hits Central Philippines. CNN. http:// edition.cnn.com/2013/11/07world/ asia/ philippines-typhoon- haiyan/. Accessed 15 September 2016.

New World Encyclopedia. (n.d). Disaster relief. http://www.newworldencyclopedia.org/ entry/Disaster relief. Accessed 17 February 2017, Accessed 15 September 2016.

Poemeleon. (2005) Luisa A. Gloria. Poemeleon: A Journal of Poetry. http:// www.poemeleon.org/luisa-a-igloria/. Accessed 17 January 2018.

Romero, P. (2013, November 16). Eastern Samar is gone. The Philippine Star. http:// www.philstar.com/

headlines/2013/11/16/1257217/eastern -samar-gone. Accessed 4 July 2017.

Rowland, A. (2014). Poetry as Testimony: Witnessing and Memory in Twentieth-century Poems. London: Routledge.

Rueda, R. B. (2014). To the Donors. In Eileen R. Tabios (Ed), Verses Typhoon Yolanda: $A$ Storm of Filipino Poets, (p. 82). Philippines: Meritage Press.

Santos, P. V. M. (2011). Uran, Uran, Tagantan: Mga Babala sa Pagbabago ng Klima sa Rawitdawit Bikol. Storm Signals: Climate Change on Bikol Poems. MALAYA, 24(1), 
2011, pp. 65-79.

Sipin, M. (2014, June 24). Typhoon Yolanda and the Art of Call-and-Response, Review of Verses Typhoon Yolanda: A Storm of Filipino Poets, edited by Eileen R. Tabios and Outpouring: Typhoon Yolanda Relief Anthology, edited by Dean Francis Alfar. Hyphen. http:// hyphenmagazine.comblog/2014/6/26/ books-typhoon-yolanda-and-art-calland-response. Accessed 21 September 2015.

Solnit, R. (2010). A Paradise Built in Hell: The Extraordinary Communities That Arise in Disaster. London: Penguin.

Strobel, L. M. (2014). Foreword. In Eileen R. Tabios (Ed), Verses Typhoon Yolanda: A Storm of Filipino Poets. Meritage P.

Sunico, R. C. (2014). Diptych, Hindi Selfie. In Regina Abuyuan (Ed), Agam: Filipino Narratives of Uncertainty and Climate Change, (p. 7). Quezon City: ICSC.

Tabios, E. R. (Eds). Verses Typhoon Yolanda: A Storm of Filipino Poets. Philippines: Meritage Press.

--- --. Introduction. In Eileen R. Tabios (Ed), Verses Typhoon Yolanda: A Storm of Filipino Poets, (pp. 15-17). Philippines: Meritage Press.

The Divine Mercy. (2018, March 13) "The Hour of Great Mercy." http:// www.thedivinemercy.org/message/ devotions/hour.php.

Wang, Z. (2009). 'Our Common Sufferings': Reflections on the Ethical Dimensions of Contemporary Disaster Poet ry. Journal of Cambridge Studies, 4(4), 114-126.

Yuson, K. (2015). Islands of Words \& Other Poems. Manila: UST Publishing House. 